\title{
Heritage Lost or Fortune Found: \\ Issues and Dilemmas concerning Tourist Development within Local Communities
}

\section{Glenn Ross}

\author{
School of Business, James Cook University
}

The distinction between the past, present and future is only a stubbornly persistent illusion. Albert Einstein.

The past, for individuals and for communities, has a potent presence; it has, in no small measure, the power to shape perceptions of current well-being as well as optimism for the future. Major discontinuities as between the past and the present can occasion widespread and negative consequences in the life of many members of a community; this is particularly so if such changes are perceived as having been imposed without prior consultation and agreement. The severity of this situation is even further compounded if changes lead to a diminution or degradation of heritage and cultural environments within a community. For many community embers, a profusion of shopping centres, of roads and highways and of leisure facilities can be no adequate replacements for the loss of their historical and cultural heritage; these typically constitute vital elements of their community and indeed individual identity. Nor can an increase in various types of employment adequately replace an abiding sense of personal well-being that frequently accompanies sensitive and competently-managed change, the hallmark of which would see the interests and rights of community members, both the powerful and the powerless, taken into account and not subordinated in the maximization of profit. Whilst tourism development is often widely regarded as heralding unalloyed riches to those communities in which it appears, this paper examines some of the more baleful effects upon heritage that have now been associated with unrestrained and insensitive tourism development in tropical North Queensland. The paper presents issues found most problematic to many local residents; it then examines the historic precinct of Cannery Row in Monterey, noting some of the less desirable changes to heritage that have been occasioned by tourism development in recent years. Finally, suggestions are offered in regard to how local community members might be more empowered in their responses to future unrestrained negative developments affecting their local heritage.

\section{Issues and Dilemmas}


Tourism is often represented as bringing considerable benefit to a community and its residents; indeed many small, isolated and declining communities can come to regard tourism as some form of economic salvation, a regional miracle cure when threatened with the multiple threats of declining populations, shrinking employment prospects and widespread negative perceptions among younger citizens concerning the viability of their future therein. What, however, is not so often conveyed involves the accompanying deleterious effects of tourism development, effects that many residents in these communities experience as alienating and even destructive of those elements of community life important to their wellbeing as individuals. Larger cities such as New York, London, Paris or Sydney may easily be able to absorb or adapt to the changes occasioned by tourism development, yet smaller communities (such as are found in the Northern Australian tropics), particularly those in rural contexts, those enjoying a traditional way of life, and those whose smaller size cause their very essence to change beyond recognition are among the communities most likely to report the presence of deleterious effects of tourism development: a diminution of cultural identification, a loss of meaningful and familiar heritage sites and contexts, a noticeable lessening of shared cultural authenticity, and even the rise of social conflict among people who formerly enjoyed amicable relationships with each other (Allen, Long, Perdue and Kieselbach, 1988; Brougham \& Butler, 1981; Lankford \& Howard, 1994).

It is often the case that when heritage sites and their contexts are destroyed, degraded or substantially altered as the result of tourism development, many local residents are likely to perceive major losses to their cultural understanding and thus to their very cultural identity; it may even be the case that some efforts at amelioration can themselves occasion further destruction to authenticity and identity. The conservation of buildings, for example, if done for the primary purpose of providing tourist plant and facilities, can risk superficiality perceptions being generated among visitors, socio-cultural irrelevance among locals, and a general loss of community values to the detriment of both local residents and those who visit the region or place (Besculides, Lee \& McCormick 2002; Francillon, 1975, Rodrigues, 1994).

Confected cultural tourism settings may appear in many forms, such as historic buildings that have been altered to be tourist attractions yet have little resemblance to the original in style or functionality; this contrivance may also be manifested in cultural events that purport to recall, even to reenact, some significant historic occasion. There are, however, a number of consequences, particularly for local people. These arise from the lack of authenticity in 
regard to such buildings and events. Perhaps most salient of all is that many in the local community are aware that the phenomena and practices are not genuine; they may even come to regard them as subjects of irrelevance, of ridicule or even open to refutation in various media. Many locals may also be aware that these confections exist or happen solely for the tourist, and often not for the people in whose community they are situated, the people to whom they once belonged or for whom they were originally reenacted (Coomansingh, 2004, Tosun, 2002).

It is often hurtful and even offensive for many local community members, particularly those who have long resided in a community, is to witness the process of manufactured authenticity that may come to surround confected historical or cultural tourism contexts. Over time, and with the intended or unintended efforts of marketing organizations, of enthusiastic tour guides, of glowing yet less than accurate interpretation material, manufactured heritage places and events initially lacking in authenticity may come to develop a patina of genuineness, and are then so regarded by many visitors. However, for older and long-term residents, such an eventuality can engender feelings of resentment and deep loss at this cultural degradation. Moreover, such profound negative effects are seldom appreciated by those enthusiastically advocating the positive benefits of tourism development, particularly those advocates for a type of development that sees no great need for the sort of checks and balances that might mitigate this loss of authenticity (Ross 1991, 1998, in press).

\section{Cannery Row}

Fotsch (2004) has offered an illuminating analysis of the impacts of tourism upon the heritage neighbourhood known as Cannery Row, located in Monterey, California. Cannery Row has had a number of lives, ranging from sardine processing to that of a revered site visited by a relatively small number of literary travelers seeking to see and to imbibe the spirit of a place made famous by the author John Steinbeck. In more recent times, however, Cannery Row has sought to cater for a much wider segment of visitor, and not simply those whose knowledge and affection for literature has brought them on a quest to the place of Steinbeck's famous novel. Along with these changes in the visitor profile and volume Fotsch reports a major alteration to the cityscape, with reconstructed and refurbished historic buildings serving as the background for the many gift shops, restaurants and other food and catering outlets. Fotsch seeks to adumbrate a number of vital social processes that have brought change to historic neighbourhoods; he has also sought to gauge the extent to which such 
processes (i.e. standardization, commodification, and historical distortion) are manifest in present-day Cannery Row.

\section{(1) Standardization}

Fotsch describes this first process as the standardization of space, and sees it as embodying the tendency for many tourism precincts to resemble each other. This is caused, in no small measure, by the influence of multinational corporations within industries such as food and catering, hospitality and retail. The theming of environments and city quarters also has a prominent role in standardizing the physical space of tourist environments that may well have been much more diverse and distinctive historical localities in former times. Fotsch concludes that the effects of such a process may now be discerned in Cannery Row; whilst he finds that not all of the historic environment has been standardized - he points out, as an example, that the facades of former canneries may still be seen, allowing some measure of distinctiveness to the historic environment - he does however find that overall the shops, the restaurants, the hospitality establishments and the retail outlets are most definitely standardized, and are generally little different to those that may be found in other tourist precincts in cities far from Cannery Row.

\section{(2) Commodification}

Fotsch argues that when a region or community represents its heritage value to the wider world, it typically seeks to avoid the mundane and the familiar; rather it would likely emphasize uniqueness. He does however warn that when historic contexts are redeveloped so as to suit a marketing perspective or campaign, this uniqueness can quickly evaporate. Commodifying historic contexts, particularly for the purposes of engendering consumption within nearby shopping malls, not only degrades the authenticity of the once-unique neighbourhood for the local people, but also diminishes or destroys those perceptions of distinctiveness that may have persuaded visitors to travel to this place. This commodification Fotsch finds not to be a major problem for Cannery Row; consumption as an end in the process of refurbishing of the past appears not to be a pervasive force operating here; the purpose for many visitors is, he finds, still the civic facilities, the Steinbeck displays and even the memorabilia collections located within a number of stores. It would therefore seem the case that Cannery Row has thus far largely avoided the primary use of refurbished heritage as a tool to bring focus upon and to enhance the turnover of the ubiquitous shopping mall. 


\section{(3) Historical Distortions}

Community heritage buildings and locations can easily loose their rich and complex traditions, and be turned in to a simplistic and manipulated interpretation of the past. Fotsch, echoing previous commentators in the heritage field, makes the point that tourists are often presented with a positive, even a sanitized, view of the past; this is done he asserts, on the understanding that people are assumed less likely to visit heritage contexts that do not convey a whole-heartedly positive view of the past. Not only has this assumption regarding tourists and positive interpretations been frequently challenged by those researchers working in domains such as battlefield tourism, dark tourism, and the tourism of natural disasters, but it also leads to a fundamental distortion of events and circumstances that have shaped heritage phenomena. Moreover, such a sanitizing process risks seriously misinforming visitors whose purpose in coming to that place is to learn and to understand how that heritage phenomena came about.

In regard to Cannery Row, the present-day focus upon Steinbeck and the fictive characters and events about which he wrote obscures, even ignores the actual history of the people who lived in the Row; these people and their daily struggle as part of the relatively brutal canning industry receive scant attention. Rather, it is said to be Steinbeck's fiction, as seen with nostalgia and through rose-coloured glasses, which receives the attention and creates the visitor reality. However Fotsch, in his study finds that the real history is not entirely absent; he notes that there are now a number of small collections of exhibits, memorabilia, signs and even a few small residential buildings that attempt to convey the harsh conditions under which people lived and worked. Notwithstanding this, Fotsch questions the degree to which these relatively few symbols and insights do actually impact upon most visitors in the creation of their impressions.

Fotsch has provided an enlightening though disconcerting analysis of the effects of tourist development upon the heritage of Cannery Row. The impacts of this development have involved costs in the life of the local community and its members. There has been revealed a process of standardization wherein the physical manifestation of the Row now, more than ever before, resembles a plethora of other tourist places around the world. There is also evidence, he concludes, of a tendency toward historical distortion; despite the constructed tourism image which involves Steinbeck, his novel and its characters featuring prominently, there is a more representative though harsher narrative that is left largely untold. Not only are 
tourists short-changed by this, but so too are local people, many of whom may come to perceive that the image-makers regard their past as either irrelevant or too shameful to recall and represent in an accurate manner. Fotsch would generally conclude that there ought to be a process of ongoing scrutiny regarding the presentation of popular heritage; it should, he avers, be the subject of debate, of criticism and of suggestions for improvement when found wanting. Such a recommendation would seem particularly apt in regard to tropical regions and destinations, many of which have experienced, or are presently experiencing the effects of tourist development. Tropical places, whether for good or ill, are widely perceived to be excellent refuges for the peoples of wealthier nations seeking to escape the rigours of midwinter in their homelands; such patterns and preferences, over time, can exert an exorable pressure upon development in host communities. A number of commentators such as Fotsch would suggest that it is the local community that ought to have a deciding influence upon the nature and the degree of tourism development, particularly in domains such as heritage.

\section{Responses}

There have been a range of suggested responses to the various effects upon community heritage occasioned by tourism development. One strategy in particular stands out as having the hallmarks of equity and of effectiveness, that of incorporating the local community in decision-making in the face of development; this is particularly salient in regard to that development the effects of which will alter the nature of local heritage and thus the manner in which local people come to understand their community and even their own lives (Aas, Ladkin \& Fletcher, 2005; Easterling, 2005).

There are various levels of empowerment for community participation. One useful model suggests a two-tiered approach, the first rung of which might be termed secondary stakeholding (Stolton \& Dudley, 1999). At this level, local community members have a recognized right to participate, to advise, and to recommend; they are not, however, given the influence to alter or mitigate development decisions that are likely to affect them; thus even if advice is given and constructive suggestion made, it may not necessarily be reflected in the outcome. In contrast, primary stakeholders, be they governmental or civic authorities, influential corporations or others directly involved in the developmental process, generally have influence in respect of how, when and in what circumstances a development may proceed. It is not until local residents and their immediate and direct representatives have a seat at the primary stakeholder's table, and enjoy some potential measure of influence over 
decisions likely to be deleterious to their heritage environment, that community empowerment will be seen to have a reasonable level of reality. Until that time, there are going to be a range of local individuals and groups, such as older citizens, long-term residents, those whose identities are bound up with the history of their local community, who may well feel relatively disempowered in the face of heritage degradation over which they perceive little or no control.

\section{List of Works Cited}

Allen, L.R., Long, P.T., Perdue, R.R. \& Kieselbach, S. (1988). The impact of tourism development on residents' perceptions of community life. Journal of Travel Research, 27, $16-21$.

Besculides, A., Lee, M. E., \& McCormick, P.J. (2002). Residents' perceptions of the cultural benefits of tourism. Annals of Tourism Research, 29, 303-319.

Boyton, L. (1986). The effects of tourism on Amish quilting design. Annals of Tourism Research, 13, 451-465.

Brougham. J.E. \& Butler, R.W. (1981). A segmentation analysis of resident attitudes to the social impact of tourism. Annals of Tourism Research, 8, 569-590.

Coomansingh, J. (2004). The nasty side of tourism development: An example from Trinidad and Tobago. eReview of Tourism Research, 2, 1-7.

Easterling, D. (2005). Residents and tourism: What is really at stake? Journal of Travel and Tourism Marketing, 18, 49-64.

Francillon, G. (1975). Tourism and Bali: Its economic and socio-cultural impact-three points of view. International Social Science Journal .27, 723-752.

Fotsch, P. (2004). Tourism's uneven impact - History of Cannery Row. Annals of Tourism Research, 31, 779-800. 
Lankford, S.V. \& Howard, D.R. (1994). Developing a tourism impact attitude scale. Annals of Tourism Research, 21, 121-139.

Rodrigues, S. (1994). The Tourist Gaze, Gentrification and the Commodification of Subjectivity in Taos. In. R. Francaviglia \& D. Narrett (Eds.), Essays on the Changing Images of the Southwest. pp. 105-125. College Station, TX: Texas A\&M University Press.

Ross, G. F. (1991). Community impacts of tourism among older and long-term residents. Australian Journal of Aging, 10, 17-24.

Ross, G. F. (1992). Resident perceptions of the impact of tourism on an Australian city. Journal of Travel Research, XXX, 13-17.

Ross, G.F. (1998). The Psychology of Tourism. Second Edn. Melbourne: Hospitality Press.

Ross, G.F. (in press). The poignancy of times past: Heritage travel motivation among seniors. In B. Prideaux, D. Timothy \& K. Chon (Eds.), Heritage and Cultural Tourism in the Asia Pacific Region. NY.: Hawarth.

Stolton, S. \& Dudley, N. (1999). Partnership for Protection - New Strategies of Planning and Management of Protected Areas. London: IUCN Earthscan.

Tosun, C. (2002). Host perceptions of impacts - A comparative study. Annals of Tourism Research, 29, 231-253. 